\title{
Food Security Issues in The Context Of State Regulation And Public Administration
}

\begin{abstract}
Anush Balian , doctor of economic science, professor Vice-president of NAAS National Academy of Agrarian Sciences, Ukraine, https://orcid.org/0000-0003-2190-2022, balianrec@gmail.com

Iryna Koshkalda, Doctor of Economic Sciences, Professor, Head of the Department of Land Administration and Cadastre, Dokuchayev Kharkiv National Agrarian University, Kharkiv, Ukraine, irinavit1506@gmail.com,

Lesia Sheludko, Candidate of Economic Sciences, Associate Professor of the Department of Applied Economics and International Economic Relations, Dokuchayev Kharkiv National Agrarian University, Kharkiv, Ukraine, lesya10081981@gmail.com

Iryna Sedikova, Doctor of Economics, Professor of the Department of Management and Logistics Odessa National Academy of Food Technologies, irina-sedikova@ukr.net, https // orcid.org / 0000-0001-5684-6927 Igor Savenko, Doctor of Economics, Professor of the Department of Management and Logistics Odessa National Academy of Food Technologies, iisavenko52@ukr.net, http://orcid.org/0000-0001-7901-6360

Oleksandr ZHEMOYDA, Doctor of Economics, Professor Department of Public Administration and Innovation Management, National University of Life and Environmental Sciences of Ukraine Kyiv, UKRAINE
\end{abstract}

\begin{abstract}
The article considers the definition of food security, which is defined by domestic and foreign scientists. Accordingly, the authors' interpretation of the term "food security" was formulated, which a set of social and economic relations developed due to providing the human with food, relevant standards for quality and quantity based on the innovative development of reproduction processes in agriculture and economic security of the agri-food sector. At the same time, the issues of providing food security by the state are combined with the tasks of innovative development of reproduction processes in the regions and agricultural producers, in particular. Based on this definition, a system of principles of state regulation of food security issues was proposed. They are as follows: stability of the legal framework governing economic processes; production stability; competitiveness of food, enterprises, and organizations; affordability of food products for all population groups; efficient use of land, production, and labor resources; diversification of food stocks; protection from external and internal threats to the agri-food sector of the economy; social and economic orientation of the country's development. According to the main components of food security, an analysis of the level of food security in Ukraine was conducted using a SWOT-analysis. Analytical research was conducted on the main components of food security - affordability, adequacy of food, and its quality and security. Besides, this type of analysis involves identifying threats to the development of the object, which exist and may arise in the future. According to the results of the SWOT-analysis, strategic actions were identified that determine the directions of the state regulation to increase the level of food security of Ukraine, which can be grouped and characterized as financial and economic, conjunctural and competitive, socially-oriented, scientific and innovative, international, and legal.
\end{abstract}

Keywords: food security, state regulation, quality and security, public administration, public policy. government regulation, environmental safety.

Received: $14.12 .2020 \quad$ Accepted: 18.01 .2021
Published: 05.02.2021

\section{Introduction}

Ensuring food security for modern society is one of the key issues in solving the problem of economic and national security, which is associated with the systemic crisis and recession in all sectors of the economy, the global financial crisis, and the economic crisis in Ukraine and requires clear strategic priorities of state policies in various sectors. As stated at the World Food Summit, which was convened in response to widespread malnutrition and growing concerns about the ability of agriculture to meet future food needs: "every man, woman, and child has the inalienable right to be free from hunger and malnutrition to develop their physical and mental abilities". Thus, the first brick in the definition of "food security" was laid []. The most famous theory of food security is the teachings of A. Maslow, which determines the importance of needs. The primary ones are physiological needs, among which hunger comes first (Vinogradova, E., Nikoliuk, O., Galimova, A., 2020) ]. The essence of food security and strategies for its provision has been studied by well-known domestic scientists, such as V. I. Vlasov, (Dragan Ivan.O., 
Kovalova Olena, Gryshchenko Iryna, Ridei Nataliia, Livinskyi A, 2020)], Yu. Ya. Luzan [], (Gryshova, I.; Shabatura, T.; Girdzijauskas, S.; Streimikiene, D.; Ciegis, R.; Griesiene, I., 2019)], (Wadim Strielkowski, Gryshova I.Yu, 2018) and others. The authors worked out the issues of improving food security management, identifying the features of food security at the regional level, specifics of using methodological approaches to assessing food security. At the same time, insufficient attention is paid to the problems of developing strategic directions of the state policy of food security. As noted by U. V. Ivanyuk, the essence of the concept of "food security" should be considered as an integral part of state economic security, which meets the needs of the state and the population in food .

According to V. Shkaberin, food security is the state of the economy provided with appropriate resources, potential, and guarantees, which, regardless of internal and external threats, preserves the unlimited ability of the state (society) and ensures economic and physical affordability of vital products for the whole population in quantities, quality, and range sufficient for the expanded reproduction of each person under the usual conditions and the minimum necessary to maintain health and efficiency in food emergencies .

According to the definition given by V. Vlasov, "food security is a system of economic, organizational, technological, social, environmental, and other factors aimed at stable functioning of the agribusiness to satisfy the population with diverse and competitive food products according to scientifically sound standards, the formation of necessary reserve stocks and export of surplus products . He points out that the vulnerability of food supply in case of complications during the production of certain foods from imports should be no more than $5-8 \%$ and these should be the products, which are not possible to produce under current natural conditions.

A similar interpretation is presented in the Concept of Economic Security of Ukraine, according to which "food security" is the state of protection of the population from malnutrition, especially from hunger, and availability of necessary state opportunities for this .

S. Nesterenko considers food security as the ability of the domestic agribusiness to produce and supply to the domestic market and state reserves food products and resources in the required range, in sufficient quantities and quality, taking into account a social structure of the population and an actual level of income, which provide their physical and economic affordability and food independence of the country .

The term "food security" carries a broad semantic load, which reflects the sufficient quantitative provision of residents with the necessary basic food and biologically active substances and compounds daily. Insufficient human supply of essential amino acids, vitamins, minerals, and other substances is referred to as "hidden hunger" due to greater health hazards and transmission of negative hereditary traits.

However, O. I. Hoychuk considers "food security" in a narrow and broad sense, respectively, as a "state of the economy" and as a "guaranteed ability of the state to meet the needs of the population presented by each citizen with food in the required volume, range, and quality at a level that ensures health and intellectual development of a person, on the principles of self-adequacy of basic products and their economic and physical affordability, regardless of the influence of external and internal factors"

I. S. Chornodid adds three points to the interpretation of food security: the family, the development of the nation, and sustainable economic development. According to the author, food security should be understood as a level of food provision that guarantees social and political stability in society, survival and development of the nation, individual, and family, sustainable economic development .

In the current scientific literature, the concept of "food security" is defined as the most important element of national economic security and involves the proper functioning of such a biological system as man, mainly through domestic food production, taking into account product quality standards, protection from substandard products and the domestic market - from surplus, dumped imports of agricultural products, the creation of reserves, stocks, and conditions for entering the foreign market of agricultural producers.

One of the notions of food security is "guaranteed, reliable, and adequate supply of basic foodstuffs, no danger of hunger and malnutrition". In a broader sense, food security is considered as the ability of the state (providing adequate resources, capacity, and guarantees) to meet the needs of the population in food mainly through domestic production at a level not lower than medical standards.

At the same time, food security is seen as the main driving force and paradigm that motivates people to develop and which can be achieved by carrying out parallel actions at the macro (national) and micro (household and individual) levels, and, accordingly, the result directly depends on which food security dimensions are assessed .

Lilian Korir, Marian Rizov, and Eric Ruto consider food security in terms of price elasticity and food costs, and state that rising relative food costs have worsened food security, and households that rely 
on informal markets and live in the rural area suffer the most. To improve food security, targeted income support may be a more effective policy than price support, given the much greater elasticity of estimated costs .

In our opinion, the category of "food security" should be considered as a set of social and economic relations developed due to providing the human with food, relevant standards for quality and quantity based on the innovative development of reproduction processes in agriculture, and economic security of the agri-food sector. At the same time, the issues of providing food security by the state are combined with the tasks of innovative development of reproduction processes in the regions and agricultural producers, in particular.

According to the Resolution of the Cabinet of Ministers of Ukraine "Some issues of food security" № 1379 dated 05.12.2007, the assessment of food security in Ukraine is based on the following indicators: daily energy value of human nutrition, providing a human diet with basic products, adequacy of grain stocks in state reserves, economic affordability of food, differentiation of the cost of food by social groups, the capacity of the domestic market of individual products, and food independence for individual products .

The role of the state in addressing food security issues is to ensure that all groups have access to sufficient quantity and quality of food. The basic principles of state regulation of food security are shown in Fig. 1.

Integrating the legal framework in the system of the principle of stability necessitates the functioning of the legal environment, which regulates the development of market processes and provides for the growth of social production and increasing the economic potential of individual economic entities, industries, and the economy as a whole. The principle of stability of production involves the gradual continuous movement of the economic system under the influence of a set of positive internal and external factors and conditions of its operation. The affordability of food products for all population groups, as a principle of food security, causes a constant increase in the total social product aimed at meeting the needs of the population and ensuring sufficient quantity and quality of food for all categories of the population. It also creates economic conditions that are the foundation for further powerful development of aggregate social product production. The principle of efficient use of land, production, and labor resources ensures full compliance with the harmonious combination of the use of available resources of economic entities and ensuring the conditions for their sustainable development. The principle of affordability and self-adequacy of basic food creates the basis for the production of highquality products and services necessary to meet the general needs of the population. The principle of the social and economic orientation of the country's development directs the activities of economic relations to improve living standards, create conditions for physical and economic affordability for all segments of the population to quality food, environmental protection, and protection of human rights. The principle of protection against external and internal threats to the agri-food sector of the economy involves timely detection of all negative factors that may affect the activities of economic entities, their profit sufficient for expanded reproduction, providing employees with high levels of material goods, improving solvency and quality of life, development of personality and protection of human rights, and formation of the socially-oriented economy. It also provides for the participation of all levels of government and hierarchical management in ensuring food security on favorable terms for all economic entities. 




Fig. 1. A system of principles aimed at increasing food security

Having analyzed the work of Samira Choudhurya and Derek Headeyb , the diversification of food stocks is also proposed as one of the principles of food security, as appropriate import and export policies are needed to ensure food adequacy and diversity for the population. It follows that the quantity and variety of food ensure the production of its main kinds in the regions and the creation of stocks or imports.( Hryshchenko Iryna, Lavshchenko Svetlan, 2020)

The affordability of food to all population groups is determined by the state of processing and storage, the development of retail chains and proximity to markets, which, in turn, affects the quality, security, and balance of food. Protection against external and internal threats to the agricultural sector of the economy, increasing import dependence, increasing the purchasing power of the population is of particular importance and is an integral part of food security.

According to existing ideas, the reliability of food security is achieved through self-adequacy in food, as well as the availability of funds for food imports in the required amounts. That is, food supply should be invulnerable even in the event of rising prices, lack of currency, the embargo on foreign food supplies, and so on. This is also stated in research, where it has been proven by a survey that income and education have the greatest impact on food security.

The Intelligence Division of The Economist with the advisory assistance of an expert group developed a Methodology for calculating the Global Food Security Index. The expert group included experts from the academic, non-profit, and governmental sectors, such as the World Bank, Tufts University, the International Institute for Rice Research, the Institute for International Food Policy Research, and the Chicago Board of Global Affairs to help select and prioritize food security through transparent and sound methodology, review the framework, selection of indicators, weighing, and general construction of the Global Food Security Index .

The Global Food Security Index includes affordability (measures consumers' ability to buy food, their vulnerability to price shocks, and availability of programs and policies to support shocks in the event of shocks), adequacy (measures the adequacy of national food security, the risk of supply disruptions, the national potential for food distribution and research efforts to expand agricultural production), quality and security (measures the diversity and nutritional qualities of medium-sized diets and food security), natural resources and adjustments (assesses the country's impact on climate change, its vulnerability to natural resource risks, and the way the country adapts to these risks).

The index also examines the risk to food security from the effects of climate change and other natural resource problems. The most interesting for our study are the key results for 26 European countries. Unfortunately, Ukraine is not in the most favorable position and ranks last in some indicators. 
For example, the highest value of GDP per capita is Ireland - 83,790 US dollars, and the lowest - Ukraine 9,253 US dollars.

Europe, as a region, is a strong player in the global economic process, second only to North America. However, there is a clear gap between food security in Western and Eastern Europe, where Ukraine belongs (Fig. 2).

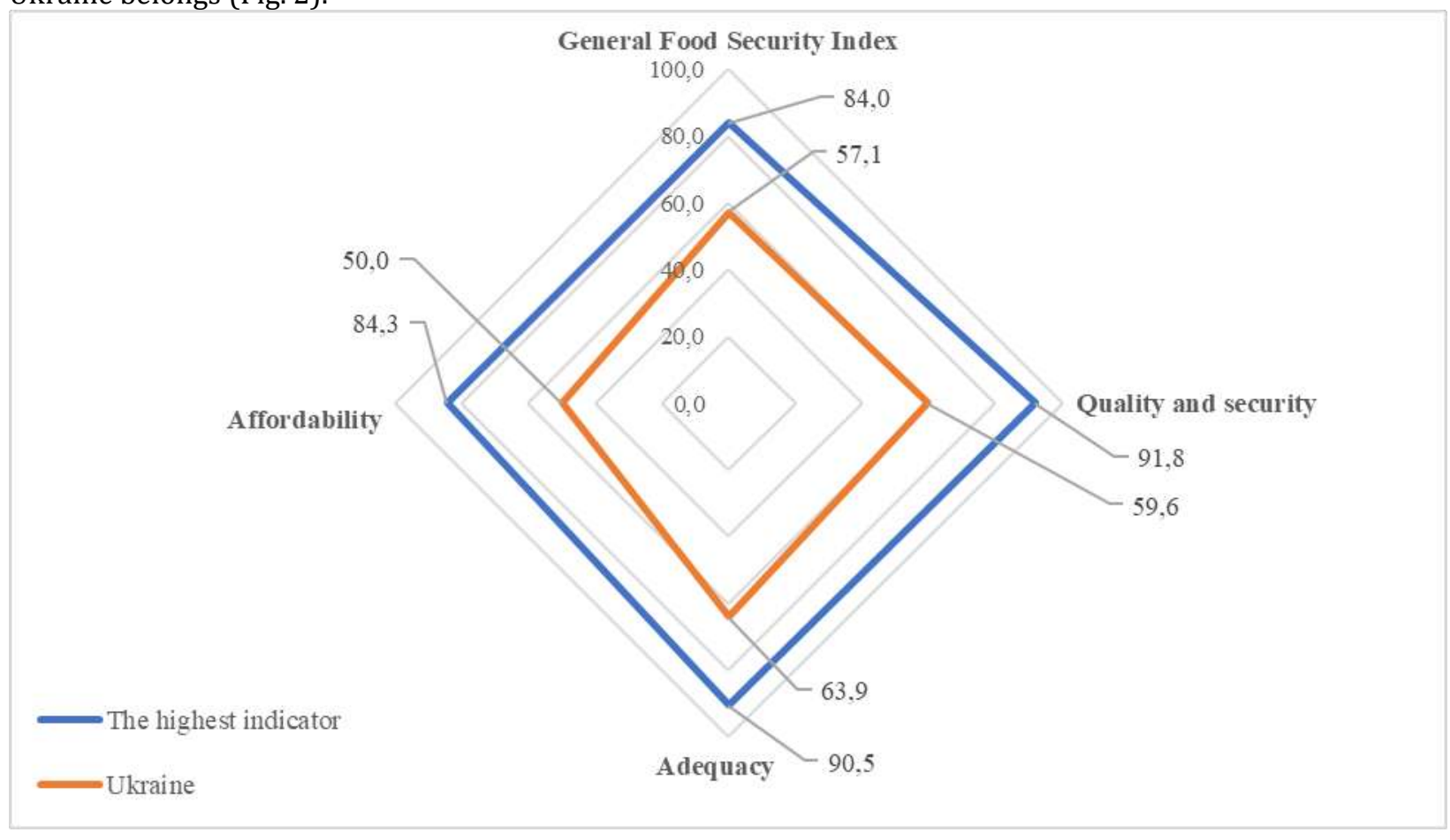

Fig. 2. Food security indices in Ukraine and Europe

(the highest rate)

In Western Europe, most countries are part of the EU, so the EU single market allows for dutyfree trade of agricultural products, which is a key factor in ensuring affordable food supply in the region. As Ukraine is outside the EU, many agricultural producers do not have access to state support and face more systematic barriers, such as poor agricultural infrastructure and a higher risk of political instability and corruption, which has been crucial in Ukraine's position (Table 1).

Table 1

Ukraine's place among 26 European countries in terms of food security

\begin{tabular}{|l|l|l|l|l|l|l|l|}
\hline $\begin{array}{l}\text { General Food } \\
\text { Index }\end{array}$ & Security & \multicolumn{2}{l|}{ Adequacy } & \multicolumn{2}{l|}{ Affordability } & \multicolumn{2}{l|}{ Quality and security } \\
\hline $\begin{array}{l}\text { Countries' } \\
\text { rating }\end{array}$ & $\begin{array}{l}\text { Indicato } \\
\text { rs }\end{array}$ & $\begin{array}{l}\text { Country's } \\
\text { rating }\end{array}$ & $\begin{array}{l}\text { Indicat } \\
\text { or }\end{array}$ & $\begin{array}{l}\text { Country's } \\
\text { rating }\end{array}$ & $\begin{array}{l}\text { Indicat } \\
\text { or }\end{array}$ & $\begin{array}{l}\text { Country's } \\
\text { rating }\end{array}$ & $\begin{array}{l}\text { Indicat } \\
\text { or }\end{array}$ \\
\hline 1. Ireland & 84,0 & 1. Ireland & 90,5 & 1. Switzerland & 84,3 & 1. Finland & 91,8 \\
\hline 2. Switzerland & 83,1 & 2. Netherlands & 85,6 & 2. Norway & 81,0 & 2. Norway & 90,5 \\
\hline = 3. Finland & 82,9 & $=3$. Austria & 85,4 & 3. Germany & 79,1 & 3. Sweden & 89,4 \\
\hline = 3. Norway & 82,9 & $=3$. Denmark & 85,4 & $=4$. Austria & 78,6 & 4. Netherlands & 88,9 \\
\hline 5. Sweden & 82,7 & 5. Sweden & 85,0 & $=4$. Finland & 78,6 & 5. Portugal & 88,0 \\
\hline 22.Russia & 69,7 & 22. Slovakia & 78,6 & 22. Slovakia & 62,1 & 22. Bulgaria & 66,8 \\
\hline 23. Slovakia & 68,3 & 23. Greece & 77,8 & 23. Russia & 60,1 & 23. Rumania & 64,1 \\
\hline 24. Bulgaria & 66,2 & 24. Belarus & 76,0 & 24. Bulgaria & 54,2 & 24. Serbia & 61,8 \\
\hline 25. Serbia & 62,8 & 25. Serbia & 73,9 & 25. Serbia & 53,0 & 25. Ukraine & 59,6 \\
\hline 26. Ukraine & 57,1 & 26. Ukraine & 63,9 & 26. Ukraine & 50,0 & 26. Slovakia & 59,4 \\
\hline
\end{tabular}

Research results and discussion. Taking into account the defined principles and data, the growth of food security should be considered as one of the priorities of national development based on the strategy of food security, which is successfully implemented.

One of the methods of diagnosing food security at the state level is the study of the internal and external environment using s SWOT-analysis. The SWOT-analysis as a method of conducting analytical 
studies of the state of the object is widely used in strategic planning and has several advantages due to the algorithm of its implementation. The technology of any analysis involves the division of the object of study into separate components (elements) and their subsequent sequential study. In our case, the research should be conducted on the main components of food security - the affordability, adequacy of food, and its quality and security. Besides, this type of analysis involves identifying threats to the development of the object, which exist and may arise in the future. In strategic planning, it is perfect for strategy formation.

This analysis was conducted to accurately, comprehensively, and timely assess the real situation in the formation of prospects for food security and strategy for its implementation in Ukraine. The SWOTanalysis provides an opportunity for a comprehensive insight into the circumstances in which the country finds itself. In assessing the conditions within the country, such parameters as political stability, production, finance, personnel, and organizational issues, as well as other realities were taken into account. Based on the study of the impact of external conditions, the potential threats to the implementation of food security measures, as well as the opportunities leading to their successful implementation were studied (Table 2).

Table 2

SWOT-analysis of Ukraine's food security

\begin{tabular}{|l|}
\hline Internal environment \\
\hline Strong points (S) \\
\hline Affordability \\
\hline Stable food prices \\
Slight fluctuations in average food costs \\
A small proportion of the population is below the \\
global poverty line \\
Low tariff rates on imports of agricultural products \\
Availability of food security programs \\
Funding for food security control programs \\
\hline Adequacy
\end{tabular}
Adequacy

Sustainability of agricultural production Low food losses

\section{Weak points $(\mathrm{W})$}

Average monthly salary

Consumer vulnerability to price changes

Weak social protection network

Low level of gross domestic product per capita

Low level of state support for agricultural producers

Government spending on $\mathrm{R} \& \mathrm{D}$ in agriculture

Risk of political instability

Corruption

Average food security

Slight dependence on chronic food aid

Insufficiently developed production infrastructure

Weak development of transport infrastructure

Quality and security
Adequate food variety

High level of food security

High level of the population with access to drinking water

There are almost no food standards

Lack of national dietary recommendations

Lack of a National Nutrition Plan or Strategy

Lack of continuous monitoring and supervision of food quality

Low quality and protein consumption

The imperfection of the activity of the state establishments providing food security

Insufficient intake of vitamins and trace elements

\section{External environment}

Opportunities (0)

Affordability

- development of an effective pricing mechanism and creation of an interconnected system of prices for food raw materials, means of production, and goods consumed in the agricultural sector;

- increasing the level of wages and general material security of the population;

- creation of a stable regulatory framework that allows normalizing the functioning of the economic system, focused on its social significance for the population;

\section{Threats (T)}

- lack of an effective pricing mechanism;

- disparity in prices for raw materials, means of production, finished products, and services in

- lower living standards;

- discrepancy between the growth rate of prices for goods and services and wages, unemployment growth;

- lack of existing state programs for economic recovery; various fields of activity; 


\begin{tabular}{|c|c|}
\hline & $\begin{array}{l}\text { - variability of the regulatory framework governing } \\
\text { the economic activities of enterprises; }\end{array}$ \\
\hline \multicolumn{2}{|l|}{ Adequacy } \\
\hline $\begin{array}{l}\text { - restrictions on the import of imported goods, } \\
\text { analogs of which are produced or may be produced } \\
\text { by domestic enterprises; } \\
\text { - development of domestic production based on } \\
\text { increasing its volumes; } \\
\text { - development of innovations, the introduction of } \\
\text { scientific and technical progress; } \\
\text { - quotas for the export of strategic raw materials } \\
\text { and scarce food from the country; } \\
\text { - development of a strategy for a common product } \\
\text { policy, the creation of civilized channels for the } \\
\text { movement of goods, the development of } \\
\text { production and trade structures; } \\
\text { - development of market infrastructure; } \\
\text { - planning and forecasting the activities of various } \\
\text { economic entities and the entire economic system } \\
\text { based on principles acceptable to market } \\
\text { conditions; } \\
\text { - strengthening of integration processes between } \\
\text { agricultural producers and processing enterprises, } \\
\text { creation of large combined and specialized } \\
\text { enterprises with a predominant share of state } \\
\text { capital; } \\
\text { - introduction of effective and reliable information } \\
\text { systems }\end{array}$ & $\begin{array}{l}\text { - occupation of market segments by imported } \\
\text { goods, displacement of domestic producers from } \\
\text { the market environment; } \\
\text { - reduction of aggregate demand for domestic } \\
\text { goods; } \\
\text { - low level of innovations in the field of material } \\
\text { production and, in particular, in the food industry, } \\
\text { moral and physical aging of existing equipment, } \\
\text { low share of fundamentally new developments and } \\
\text { know-how, lack of a mechanism that stimulates } \\
\text { innovation; } \\
\text { - export of strategic raw materials and scarce food } \\
\text { products that are in demand among the population; } \\
\text { - instability of monetary, tax, and customs policies; } \\
\text { - lack of principles and methods of planning and } \\
\text { strategic forecasting in market relations; }\end{array}$ \\
\hline \multicolumn{2}{|l|}{ Quality and security } \\
\hline $\begin{array}{l}\text { - achieving high yield capacity of crops through the } \\
\text { use of world experience in land cultivation and } \\
\text { maintaining its condition at the appropriate level; } \\
\text { - the use of elite seed forms in production; } \\
\text { - the possibility of producing niche species this } \\
\text { year products; } \\
\text { - systematic improvement of product quality and } \\
\text { its compliance with the world level. }\end{array}$ & $\begin{array}{l}\text { - unsystematic organization of trade and market } \\
\text { complexes and lack of control over their activities; } \\
\text { - lack of reliable reporting on the activities of } \\
\text { producers; } \\
\text { - weak information base, which does not allow to } \\
\text { properly assess the quality of food }\end{array}$ \\
\hline
\end{tabular}

The food security component of food "affordability" includes the ability of consumers to buy food, their vulnerability to price changes, and the availability of policies to support consumers in case of fluctuations. High incomes, low poverty, stable food prices, strong social protection networks, and sound agricultural financing systems make Europe the region with the highest score in this category after North America. However, there are specific gaps for individual countries, especially for Ukraine. Countries should continue to monitor food affordability indicators and study subnational indicators to identify specific vulnerable population groups and regions. (Dr. Tetiana Tielkiniena, Gryshova Inna, Shabatura Tatyana, Nehodenko Viktoriia, Didur Hanna, Shevchenko Alisa., 2020)

The next component of food security, "adequacy" measures the availability of food through the assessment of factors such as the adequacy of national food security, the risk of supply disruptions, the ability to distribute products, and research to expand agricultural production. In Ukraine, political instability and corruption are the greatest threats to food affordability and, as a result, to food security. Therefore, the country must fiercely combat corruption, maintain its production and transport infrastructure - roads and railways, in rural areas particularly. (Azer Dilanchiev, Gryshova Inna, Rogach Svetlana, Diachenko Oleksii, Batrakova Tetyana, Shabatura Tatyana, 2020) Agricultural storage facilities and irrigation infrastructure should also be monitored to ensure that they are maintained and sufficient to meet the needs of the population, especially in the event of adverse climatic conditions and crop failures. Although Ukraine has low indicators of transport infrastructure, there is room for improvement. The operation of rail, air, and port infrastructure plays an important role in food transportation, though the country needs strong road systems. This is a signal to improve transport links and food affordability for rural and remote areas, in particular. Reclamation infrastructure lags far behind other European 
countries, and each country's irrigation needs are different. The relatively high risk of drought in Ukraine suggests that irrigation will be important for horticulture now and in the future. Thus, it may be a promising area for investment.

"Quality and security" of food is an important component of Ukraine's food security, as the country has a sufficient level of food diversity, and at the same time, the lack of micronutrient and protein intake, likely due to low income. Taking into account the amount of protein consumed, as well as the amino acids contained in food, Ukraine has the lowest protein quality. Ukraine has a poor implementation of foodstuffs and food stocks standards and is one of the countries with the lowest food requirements. In Ukraine, there are no implemented national dietary recommendations to provide information on a balanced diet, as well as national nutrition plans or strategies aimed at improving the nutrition of adults and children.

State regulation provides for the solution of food security issues based on certain principles, the results of the SWOT-analysis, and further development of strategic actions. (Gryshova, I.; Kyzym, M.; Hubarieva, I.; Khaustova, V.; Livinskyi, A.; Koroshenko,2020)

Thus, having conducted an in-depth analysis of the level of food security in Ukraine, we propose strategic actions to increase food security in Ukraine (Fig. 3).

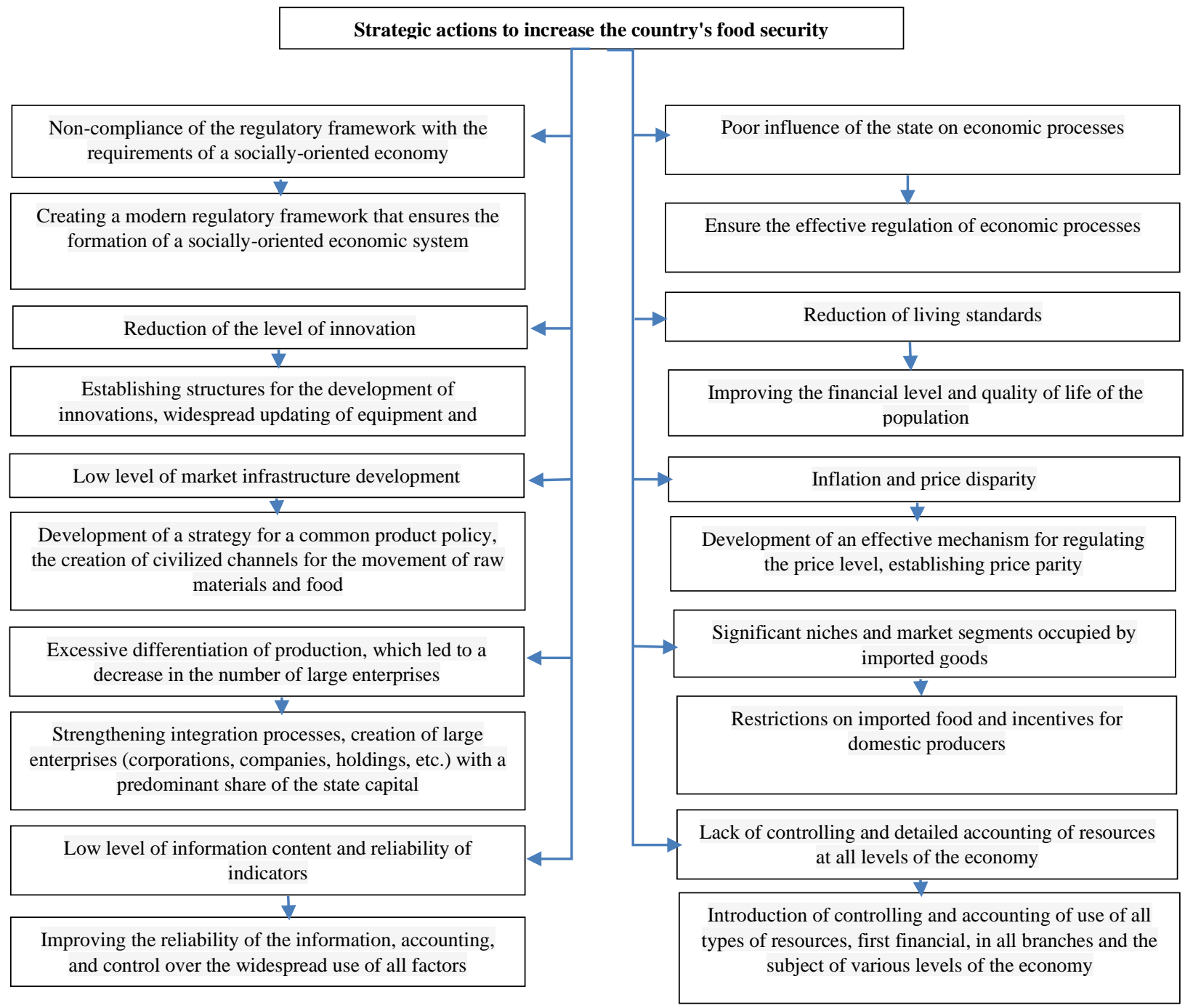

Fig. 3. Directions of state regulation to address food security issues of the country

Thus, these strategic actions can be grouped and briefly described as follows: financial and economic actions are the growth of food production, an increase in profits, an increase in productivity; conjunctural and competitive - improvement of the quality and competitiveness of products, expanding the segment and niches of the sales market; socially-oriented - improvement of the quality of life, increasing solvency, an increase in the share of wages in terms of the cost of production; scientific and 
innovative - the intensification of the pace of renewal of production, labor, and management, development of domestic innovative technologies and equipment; international - the promotion of competitive products abroad with the regulation of food exports and imports; legal - the creation of a legal basis for the balanced development of all economic entities, improving the quality of life, the agreement of interests of all levels of the economy in economic development. (Koshkalda, I., Kniaz, O., Ryasnyanska, A., Velieva, V., 2020), (Popov, A., Kniaz, O., Koshkalda, I., Trehub, O., 2019)

\section{Conclusions}

In our opinion, the category of "food security" should be considered as a set of social and economic relations developed due to providing the human with food, relevant standards for quality and quantity based on the innovative development of reproduction processes in agriculture, and economic security of the agri-food sector. At the same time, the issues of providing food security by the state are combined with the tasks of innovative development of reproduction processes in the regions and agricultural producers, in particular.

The research proposed a system of principles of state regulation of food security, namely: the stability of the legal framework governing economic processes; stability of production; competitiveness of food, enterprises, and organizations; affordability of food products for all groups of the population; efficient use of land, production and labor resources; diversification of food stocks; protection from external and internal threats to the agri-food sector of the economy; social and economic orientation of the country's development. According to the main components of food security, an analysis of the level of food security in Ukraine was conducted using a SWOT-analysis. The analytical study was conducted on the main components of food security - affordability, adequacy of food, and its quality and security. The analysis also identified threats and opportunities for the development of the object, which exist and may arise in the future. As a result of the SWOT-analysis, strategic actions were identified that determine the directions of state regulation to improve the level of food security of Ukraine, which can be grouped and characterized as financial and economic; conjunctural and competitive; socially oriented; scientific and innovative, international, and legal.

\section{References}

http://www.fao.org/wfs/index_en.htm

${ }^{1}$ Hladiy M. V., Luzan Yu. Ya. Agrarian transformations and farms in the food security system of Ukraine. Economics of agribusiness, 2020. № 5. pp. 6.

${ }^{1}$ Conditions and factors of the formation of food security of Ukraine. Economics and management of the national economy. 2016. Issue 5. pp. 65-68.

${ }^{1}$ Shkaberin V. M. State regulation of food security in Ukraine. [B. m .: b. v.], 2006. pp. 10.

1 Vlasov VI Global food issue. - Kyiv: Institute of Agrarian Economics, 2001. 506 p.

1 Scientific report: The concept of economic security of Ukraine / Head of project V. M. Heyets. - K .: Logos,1999. $56 \mathrm{p}$.

${ }^{1}$ Nesterenko SA Modern trends in methodological approaches to assessing the country's food security. Bulletin of KhNAU (Economic Sciences Series). №2. pp. 135-143.

${ }^{1}$ Chornodid I. S. Economic security as a category of economic theory. Current issues of the economy, 2003. № 11 (29). pp. 17 - 26.

1 Alekseyeva Ya. Scientific principles of determining food security. Collection of scientific works. "Efficiency of public administration", 2015. Issue 42. pp. 100.

1 Pedro Conceição, Sebastian Levine, Michael Lipton, Alex Warren-Rodríguez Toward a food secure future: Ensuring food security for sustainable human development in Sub-Saharan Africa. Food Policy. Vol. 60 (2016) 1-9/.

${ }^{1}$ Muhammad Umar, Farrukh Muhammad, Khalid Bashir, Sarfraz Hassan, Sultan AliAdil, Marit E.Kragt Mapping the food security studies in India, Pakistan and Bangladesh: Review of research priorities and gaps. Global Food Security. Volume 26, September 2020, 100370.

${ }^{1}$ Lilian Korir, Marian Rizov, Eric Ruto Food security in Kenya: Insights from a household food demand model. Economic Modelling. Volume 92, November 2020, Pages 99-108.

1 Some food security issues: Decree dated December 5, 2007, N 1379 https://zakon.rada.gov.ua/laws/show/1379-2007-п.

1 Samira Choudhurya, Derek Headeyb What drives diversification of national food supplies? A crosscountry analysis. Global Food Security. Volume 15, December 2017, pp. 85-93.

${ }^{1}$ Yun Lia, Wen Yub Households Food Security in Poverty-Stricken Regions: Evidence from Western Rural China. Agriculture and Agricultural Science Procedia 1 (2010) 386-395. 
1 Francesco Burchi a, Pasquale De Muro From food availability to nutritional capabilities: Advancing food security analysis, Food Policy 60 (2016) 10-19.

1 Regional report: Europe global food security index 2019 / https://foodsecurityindex.eiu.com/Home/Methodology.

Azer Dilanchiev, Gryshova Inna, Rogach Svetlana, Diachenko Oleksii, Batrakova Tetyana, Shabatura Tatyana. REMITTANCE LEVELS AND ENTREPRENEURIAL ACTIVITY IN POSTSOVIET COUNTRIES . JCR. 2020; 7(4): 1655-1663. doi:10.31838/jcr.07.04.271

Dr. Tetiana Tielkiniena, Gryshova Inna, Shabatura Tatyana, Nehodenko Viktoriia, Didur Hanna, Shevchenko Alisa. LOBBY LEGALIZATION - LEGAL INSTRUMENT FOR ENSURING STATE SUBSIDIES TO LEADERS OF AGRICULTURAL PRODUCERS . JCR. 2020; 7(4): 1679-1683. doi:10.31838/jcr.07.04.274

Gryshova, I.; Shabatura, T.; Girdzijauskas, S.; Streimikiene, D.; Ciegis, R.; Griesiene, I. The Paradox of Value and Economic Bubbles: New Insights for Sustainable Economic Development. Sustainability 2019, 11, 6888.

Gryshova, I.; Kyzym, M.; Hubarieva, I.; Khaustova, V.; Livinskyi, A.; Koroshenko, M. Assessment of the EU and Ukraine Economic Security and Its Influence on Their Sustainable Economic Development. Sustainability 2020, 12, 7692.

Wadim Strielkowski, Gryshova I.Yu (2018) Academic publishing and «predatory» journal. Nauka innov., 14 (1) C.5-12

Vinogradova, E., Nikoliuk, O., Galimova, A.Creation of the corporate information system based on knowledge economy. E3S Web of Conferences, 2020, 208, 03011

Dragan Ivan.O., Kovalova Olena, Gryshchenko Iryna, Ridei Nataliia, Livinskyi A. I. Assessment Of The Role Of The State As A Leader In The Demographic Development Of Ukraine. Solid State Technology Vol. 63 No. 6 (2020) p.6630-6639 http://www.solidstatetechnology.us/index.php/JSST/article/view/4400

Hryshchenko Iryna, Lavshchenko Svetlana. Impact of local market development on sustainable (stable) city development. First Conference on Sustainable Development: Industrial Future of Territories (IFT 2020). Section: Sustainable Cities and Society. E3S Web Conf. (24 November 2020). Vol. 208, 04009 (2020).

9. Popov, A., Kniaz, O., Koshkalda, I., Trehub, O. Land fragmentation of agricultural enterprises in the context of administration of land.Economic Annals-XXI, 2019, 176(3-4), стр. 80-90

10. Koshkalda, I., Kniaz, O., Ryasnyanska, A., Velieva, V. Motivation Mechanism for Stimulating the Labor Potential. Research in World Economy, 2020, 11(4), стр. 53-61 